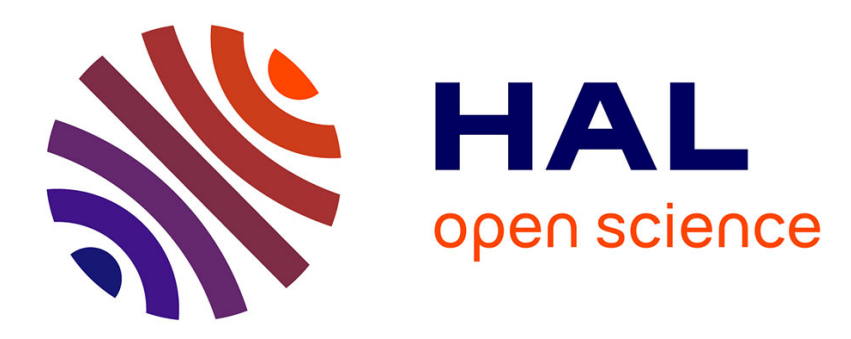

\title{
Analgesia and Sedation After Pediatric Cardiac Surgery Andy Wolf
}

\section{- To cite this version:}

Andy Wolf. Analgesia and Sedation After Pediatric Cardiac Surgery. Pediatric Anesthesia, 2010, 15 (s1 CV), pp.567. 10.1111/j.1460-9592.2010.03460.x . hal-00599905

\section{HAL Id: hal-00599905 https://hal.science/hal-00599905}

Submitted on 11 Jun 2011

HAL is a multi-disciplinary open access archive for the deposit and dissemination of scientific research documents, whether they are published or not. The documents may come from teaching and research institutions in France or abroad, or from public or private research centers.
L'archive ouverte pluridisciplinaire HAL, est destinée au dépôt et à la diffusion de documents scientifiques de niveau recherche, publiés ou non, émanant des établissements d'enseignement et de recherche français ou étrangers, des laboratoires publics ou privés. 


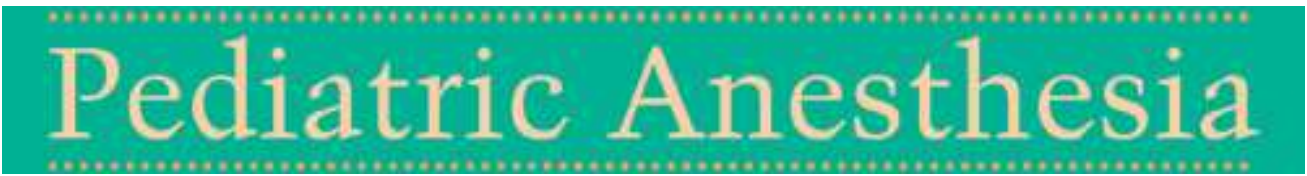

\section{Analgesia and Sedation After Pediatric Cardiac Surgery}

\begin{tabular}{|r|l|}
\hline Journal: & Pediatric Anesthesia \\
\hline Manuscript ID: & PAN-2010-0384 \\
\hline Manuscript Type: & Review (commissioned) \\
\hline $\begin{array}{r}\text { Date Submitted by the } \\
\text { Author: }\end{array}$ & 19-Aug-2010 \\
\hline Complete List of Authors: & $\begin{array}{l}\text { Wolf, Andy; Bristol Royal Hospital for Children, Paediatric Intensive } \\
\text { Care Unit; bristol childrens hospital }\end{array}$ \\
\hline Key Words: & analgesia, cardiac, surgery, pain management \\
\hline \multicolumn{2}{|l}{} \\
\hline
\end{tabular}


Analgesia and Sedation After Pediatric Cardiac Surgery

\author{
Andrew R Wolf MD FRCA \\ Professor of Anaesthesia and Critical Care, University of Bristol \\ Consultant in Paediatric Anaesthesia and Intensive Care \\ Paediatric Intensive Care Unit \\ Bristol Children's Hospital, Upper Maudlin Street, Bristol BS2 8HQ \\ Tel: 01173428843, e-mail: awolfbch@aol.com
}

Dr Lara Jackman MBBS, MRCPCH, BSc

Paediatric Intensive Care Unit

Bristol Children's Hospital, Upper Maudlin Street, Bristol BS2 8HQ

\begin{abstract}
Address for Correspondence: Professor Andrew Wolf, Intensive Care Unit, Bristol Royal Children's Hospital, Upper Maudlin Street Bristol BS2 8BJ.
\end{abstract} e-mail: awolfbch@aol.com 


\begin{abstract}
Summary
In recent years, the importance of appropriate intra-operative anesthesia and analgesia during cardiac surgery, has become recognised as a factor in postoperative recovery. This includes the early perioperative management of the neonate undergoing radical surgery and more recently the care surrounding fast track and ultra fast track surgery. However, outside these areas, relatively little attention has focused on postoperative sedation and analgesia within the pediatric intensive care unit (PICU). This reflects perceived priorities of the primary disease process over the supporting structure of PICU, with a generic approach to sedation and analgesia that can result in additional morbidities and delayed recovery. Management of the marginal patient requires optimisation of not only cardiac and other attendant pathophysiology, but also to every aspect of supportive care. Individualised sedation and analgesia strategies, starting in the operating theatre and continuing through to hospital discharge, need to be regarded as an important aspect of perioperative care, to speed the process of recovery.
\end{abstract}

Keywords: Sedation; analgesia; pediatric; intensive care; cardiac; withdrawal 
Undersedation and oversedation are both harmful. Inadequate sedation is unacceptable in a vulnerable child who may be unable to move or communicate distress due to use of muscle relaxants, while the unparalysed child may "fight" the ventilator leading to ineffective ventilation, accidental extubation or the loss of invasive access or monitors. In intensive care, agitation and inadequate sedation has been correlated with adverse short and longer-term outcome (1-2). Recent data has highlighted that intensive care and surgery is associated with long-term dysregulation of nociceptive mechanisms, which may change behaviour and responses to future sensory and pain stimuli (3). By contrast, oversedation delays recovery, promotes tolerance to the drugs and leads to distressing symptoms on their withdrawal (agitation, seizures, hallucinations, psychosis, fever and tachycardia) (4). Maintaining ideal analgesia whilst at the same time promoting earlier extubation and PICU discharge can be difficult to achieve. Infants have an almost binary state of consciousness, (5) and a normally active three year old cannot easily be persuaded to remain quiescent for long periods in the ICU environment using non-pharmacological comforting measures alone. Furthermore, in the current healthcare environment, there are considerable consumer/parental pressures to ensure that all discomforts whether real or perceived are avoided. Recent advances in drug choices, patient monitoring and other therapeutic options, however, offer new prospects for the future.

Simplistically, analgesic drugs should be given for pain relief, sedative drugs for reduction of conscious level, and muscle relaxants used only for specific situations when paralysis is 
essential (e.g. low cardiac output states, when it may be necessary to anesthetise, paralyse and cool a child). However, there is some crossover in these roles: morphine has sedative properties, ketamine provides analgesia and anesthesia and even muscle relaxants may have an additive effect on reduction of conscious state through deafferentation (6). Individual drugs have secondary properties which may be exploited therapeutically in specific situations, for example the use of high dose opioids in the management of pulmonary hypertension. Sedation and analgesia strategies need to be viewed as a collaborative effort between anaesthetist and intensivist in order to optimise the "postoperative recovery gradient" for the individual. For example, the perioperative strategy for an infant VSD may include on table or early extubation, within four hours, with continued sedation and analgesia to ensure that the infant can cope with the constraints of intensive care management. By contrast, the complex, postoperative neonate with a low cardiac output state, may have an ongoing requirement for high dose opioids, sedation and paralysis in PICU.

\section{Analgesia ( Table 1 and 2)}

Table 1 and 2 near here

Analgesic drugs comprise opioids, local anesthetic agents, prostaglandin synthetase inhibitors (NSAID's), acetaminophen, ketamine and alpha-2 agonists (clonidine and dexmedetomidine). Opioids remain the primary analgesic agents after cardiac surgery because of their high efficacy. Co-analgesia with NSAID's and acetaminophen plays a key role in reducing opioid requirements and side effects (7), which is particularly useful for fast track surgery.

Opioids have properties other than analgesia that can be exploited in the care of the critically ill child. Potent opioids such as fentanyl, sufentanil and remifentanil delivered at doses higher than that required simply for analgesia can obtund hemodynamic and adverse hormonal and metabolic responses in the critically ill. Studies by Anand and others demonstrated that highdose opioids used during surgery were associated with reduced stress response, nitrogen loss, postoperative complications and mortality (8-10) This led to a view that high-dose opioid analgesia, which aims to obtund measured responses to surgery are key to good outcome in the high-risk surgical infant. Less is known, however, about the benefits of high dose opioids 
in the context of general pediatric intensive care. Certainly, high dose opioid administration has been shown to be beneficial in the prevention and treatment of specific situations such as a pulmonary hypertensive crisis in the at risk infant (11), and may benefit patients with a low cardiac output state, or those with a critically balanced pulmonary to systemic shunt. Data is limited, however, outside these specific areas.

Control of stress responses can be achieved at much lower doses than those used in the earlier studies and exposure to high dose opioids such as fentanyl (50 $\mathrm{mcg} \mathrm{kg}^{-1}$ or higher) is associated with hypotension (12). The issue of benefits versus side effects of opioids in the critical care setting have been highlighted by the results of the "NEOPAIN" study (13) in the preterm neonate. The findings have been subject to considerable debate but suggest that in preterm neonates given morphine in a more liberal fashion than controls, observed comfort was improved at the expense of systemic hypotension. This was associated with increased risk of significant short and long-term neurological injury and adverse outcomes. Whilst management of the newborn is a special case, the inference in PICU is clear: provision of opioids mandates careful management to avoid hemodynamic instability whatever dose is provided. Children with severe cardiovascular compromise need careful hemodynamic monitoring and the availability of supportive therapy when first exposed to intense analgesia.

Neonates have both pharmacodynamic and pharmacokinetic susceptibility to sedatives and opioids, which may deter the clinician from providing effective dosing. However, unless effective plasma concentrations of the drug have already been achieved during surgery, initial loading doses may be required in the ICU. By contrast, in older infants and young children it can be difficult to maintain comfort and a relatively quiescent state without large drug doses, often in combination with multiple sedative agents. This reflects increased volume of distribution, with high clearance, that may equal or exceed that of adults, and a relative pharmacodynamic drug resistance. It is not until adolescence that responses and handling of the drugs approaches that of the adult.

Pharmacokinetics of the opioids are not only age-dependant but also affected by cardiac failure and cardiopulmonary bypass (CPB) surgery. Studies with morphine and remifentanil have shown that after cardiac surgery (14-15) there is a combination of an increase in volume of distribution and fall in drug clearance. Care therefore must be taken to provide adequate drug loading early on, whilst individualising continuous infusions over time to reflect 
reduced drug clearance, particularly in the setting of low cardiac output, and hepatic or renal impairment. Accumulation of the active metabolite of morphine, morphine-6-glucuronide, in renal failure, can lead to excessive and long-lasting sedation that delays extubation.

All opioids are associated with tolerance, resulting in increasing requirements to maintain adequate analgesia/sedation. This is accelerated by high-dose opioid techniques during anesthesia, which can cause "acute tolerance", an effect which has been shown to be more pronounced in shorter acting, higher potency opioids, such as fentanyl and remifentanil (16). Neonates undergoing ECMO require five times the initial fentanyl infusion rate by day six to achieve an equivalent level of sedation, due to a combination of enhanced elimination (17) and pharmacodynamic tolerance (18).

Morphine is more water soluble than fentanyl, with slow onset and offset, and pronounced sedative effects, which facilitates effective analgesia following anesthesia. Loading doses of $100-200 \mu \mathrm{g} \mathrm{kg}^{-1}$, followed by infusions of 10-60 $\mu \mathrm{g} \mathrm{kg} \mathrm{hr}{ }^{-1}$, provide reliable analgesia. Excessive sedation, respiratory depression, nausea and vomiting can be problematic. Patientcontrolled analgesia, using a low background can be highly effective in older children, with nurse-controlled analgesia an option for the younger child.

Fentanyl is a potent opioid, with rapid onset and offset after short-term infusion (hours) due to its lipid solubility and extensive peripheral uptake. After lengthy infusions (days), recovery can be prolonged due to its relatively long elimination half-life. Whilst analgesia can be achieved with doses of $1-5 \mu \mathrm{g} \cdot \mathrm{kg}^{\cdot} \mathrm{hr}^{-1}$, infusion rates of $10-20 \mu \mathrm{g} \cdot \mathrm{kg}^{\cdot} \mathrm{hr}^{-1}$, may be beneficial in infants with low cardiac output states, critically balanced pulmonary and systemic circulations, or pulmonary hypertension, to reduce metabolic demands and obtund hemodynamic responses to stimuli. $5-10 \mu \mathrm{g} \mathrm{kg}^{-1}$ boluses may be required for procedures such as endotracheal suctioning and physiotherapy. High doses may provide complete anesthesia and sedation for neonates, whilst older infants and children also require an hypnotic agent.

Alfentanil is highly protein bound, resulting in a small volume of distribution. It undergoes rapid hepatic metabolism to inactive compounds (19). Although less potent than fentanyl, its rapid onset and offset lend it to short-term anesthesia and analgesia. 
Despite its desirable properties, its role in postoperative pain management remains to be established, with cost and drug tolerance (23), restricting its utility to relatively short-term analgesia. Furthermore, its potency and effects on ventilation, limit its use in spontaneously breathing children and sick neonates, who can develop bradycardia and hypotension on initial exposure (22). In a study of 'fast track' pediatric cardiac surgery, it lacked superiority over fentanyl in terms of recovery and was associated with a significant reduction in heart rate (24). It has potential utility for procedural analgesia, in ventilated patients in PICU. Given as a single intranasal dose it provides an excellent pharmacokinetic profile providing analgesia for 15 minutes. This approach avoids fluctuant levels and the attendant side effects of single intravenous dose or infusion of remifentanil. Verghese et al. have reported this technique for intubation during inhalational anaesthesia with $5 \%$ sevoflurane after a single dose of $4 \mu \mathrm{g} \mathrm{kg}^{-1}$ of remifentanil (25). This exiting new approach would allow modulation of analgesia for procedures such as physiotherapy and endotracheal tube change, without having to modify existing infusions or break into the intravenous circuit to give additional bolus doses.

Once the alimentary route is effective, there is some evidence that oral opioid administration results in reduced longer-term tolerance (26-28). Certainly, the use of enteral drug administration reduces the infection-risk associated with long-term intravenous access and line manipulations (29) and should be used wherever possible. Morphine undergoes considerable first pass metabolism by the liver, if absorbed through the alimentary system, resulting in considerably greater dose-requirements than by intravenous routes, with total 
daily doses needing to be increased by a factor of five to ten in order to achieve the same level of analgesia.

\section{Local Analgesia Techniques}

Afferent pain conduction can be eliminated with effective local anesthesia, with minimal side effects. Simple local anesthetic techniques can provide an important adjunct to any analgesia or sedation regimen, by reducing the background drug requirement and that for procedural analgesia. Local anesthesia can be given by a wide variety of routes which include topical, infiltration, peripheral nerve block or central continuous block (epidural or spinal). Topical anesthesia is used regularly on the general paediatric wards and in the emergency department (ED). The use of these agents in PICU is often ignored except in non-intubated patients. The pain associated with venous cannulation is sufficiently distressing, even in a moderately sedated child, to necessitate additional sedation. If agents such as Ametop and EMLA are routinely applied in advance of an anticipated procedure, the use of intravenous analgesia and sedation can be minimised. Newer, faster acting agents are now available, including lidocaine-adrenaline-tetracaine gel (LAT gel), which is effective in as little as 10 minutes (30-31). This agent is finding increasing favor in the ED for wound suturing, with good effect. It has been suggested that its use should be extended to other areas, such as PICU, due to its rapid onset of action and excellent analgesic effects. Care does need to be given, however, to site of use, due to the adrenaline component.

Regional anesthesia for cardiac surgery remains in the domain of a few enthusiasts rather than as a mainstream technique. A variety of retrospective publications using caudal, epidural or spinal techniques have suggested value in the management of children after cardiac surgery, but the data remains limited and largely uncontrolled (32-34). A prospective randomised trial of spinal anesthesia with an indwelling catheter, demonstrated reduced stress responses and lower blood lactate concentrations compared to a high dose conventional opioid technique in children under three years undergoing major cardiac surgery (35). A similar technique to that described is currently being used by our group to provide stress reduction in the operating theatre, facilitate early extubation and minimise the requirement for systemic analgesia. 
$\underline{\text { Sedation (Table 3) }}$

Sedation is a broad term when used in the context of PICU. It may facilitate several goals including:

1. Unconsciousness (virtual anesthesia) or reduction in conscious level

2. Reduced awareness

3. Loss of explicit and implicit memory

4. Compliance with the need to lie in a confined space, attached to monitors and invasive lines

5. Prevention of distress during procedures such as physiotherapy, radiological scanning or minor surgical intervention, which may require enhanced levels

Table 3 near here

Different drugs fulfil these roles to varying extents. Benzodiazepines, for example, provide anterograde amnesia, with reduced or complete unconsciousness at different doses, whilst phenothiazines and butyrophenones (chlorpromazine and haloperidol), used as major tranquillising drugs in schizophrenia, have psychotropic properties that render the patient disinterested in activity. Some analgesic drugs reduce both pain and consciousness: ketamine provides analgesia and a dissociative anesthesia/sedation, clonidine produces analgesia and a calmed relaxed state, and morphine has additional sedative properties. Therefore, choice of a sedative regimen needs to be tailored to the individual rather than generic.

Neonates are a special group, in that morphine alone can often provide sufficient analgesia and sedation. Outside this period, however, an analgesic and a sedative drug are almost always necessary. Where neuromuscular blockade is required, a sedative drug given at an adequate dose, becomes mandatory to prevent awareness.

In the past, patients in adult ICU have been given an opioid in combination with a low dose of anesthetic agent to ensure pain relief, hemodynamic stability and tolerance to the constraints of ITU. The potentially lethal side effects of anesthetic drugs used over days have only emerged after reviews of death rates and analysis of recurring adverse events. These 
have included immunomodulation by barbiturates (36-37), adrenocortical suppression by etomidate (38) and more recently, mitochondrial dysfunction with propofol, in both adults and children (39).

As with opioids, delivery via the enteral route may avoid complications associated with intravenous delivery, provided enteric function is intact. Many of the sedative agents are well absorbed and tolerated enterally, including benzodiazepines, clonidine and chloral hydrate. An additional advantage to oral sedation is it can be weaned gradually and continued following discharge from ICU if necessary.

\section{Early Extubation}

Early extubation, with good analgesia that allows rapid mobilisation and recovery, is likely to be beneficial in terms of reducing postoperative complications, although the results of more general outcome studies remain inconclusive $(2,40)$. It should be added that a precondition of early extubation, is that the postoperative repair and cardiovascular function are adequate to support an awake, mobilising infant. Accelerated convalescence confers benefits in both medical and economic terms, in that earlier discharge from the ICU improves throughput. The last 10 years has seen a widespread acceptance of fast track pediatric surgery, with rapid extubation not only for simple cases but also more complex procedures (41-42). There may be specific advantages in immediate extubation for some cardiac conditions. For example those with single ventricle physiology (following Glenn shunt/ Fontan repair), and Fallot's Tetralogy, when reduced intrathoracic pressure, associated with spontaneous breathing, improves pulmonary blood flow and oxygenation (43).

A variety of techniques have been described, including the use of regional analgesia, however the difficulties lie not with on table extubation but with managing pain and sedation in ICU. Children need to remain sufficiently sedated after surgery to prevent restlessness with attempts to remove vital monitoring or invasive catheters. In the authors' experience, this usually necessitates a combination of both analgesia (opioids, acetaminophen and NSAIDs) and sedation (a benzodiazepine or alpha-2 agonist). Excessive use of potent opioids during surgery promotes acute tolerance, leading to a requirement for increased analgesia after surgery (16). The debate on whether "pharmacological restraint" is always preferable to limited physical restraint, such as bandages around the hands, arm splints or even true restraint, remains unresolved, and provokes strong views. 


\section{Sedation and Analgesia in the Long-stay Patient}

As the management of the cardiac surgical patient continues to improve, the need to ventilate infants over days and weeks has diminished. However, those with residual problems, that cannot be improved immediately by further intervention or who remain marginal for cardiac or non-cardiac reasons, may enter a phase of chronic sedation and ventilation as their issues resolve. Examples include those with cardiac failure, pulmonary hypertension, lung or airway disease or ongoing sepsis. These patients are the most at risk from drug tolerance and subsequent withdrawal. Some agents are considered more problematic than others: the incidence of withdrawal with midazolam has been reported as frequently as $35 \%$. Limiting midazolam infusion to $100 \mathrm{mcg} \mathrm{kg} \mathrm{hr}^{-1}$ reduces the likelihood of withdrawal but stopping the drug slowly does not reduce the risk. (45).

Techniques that can be used in PICU to limit the problems associated with long-term sedation include:

1. Drug cycling: changing pharmacological drug groups routinely to reduce the emergence of tolerance

2. Sedation holidays: temporary cessation of sedative drugs to evaluate emergence. 
3. Non-pharmacological techniques: oral sucrose, reducing environmental stress (noise, light, interruption of day-night cycle), swaddling etc

4. Transfer to oral sedation where possible

In adult intensive care percutaneous tracheostomy is often performed at an early stage. This allows the patient to be ventilated whilst awake with minimal sedation, allowing the patient to breath with support ventilator modes, cough and clear their own secretions more effectively, reducing the risks of nosocomial chest infections. Unfortunately, this technique cannot be applied in children because of the technical issues associated with smaller airways and the continuing need for sedation. Surgical tracheostomy and insertion of a long-term indwelling central venous catheter can, however, allow the patient who requires longer term ventilator support to be managed with little or no sedation

Neuromuscular blockade can be useful in patients that are difficult to ventilate, such as for inverse ventilatory ratios, high frequency oscillation, or to deliberately hyper or hypoventilate them depending on their underlying pathology (46). It continues to be used in children that require hypothermia due to dysrythmia or to reduce metabolic rate and oxygen demand. Neuromuscular blockade is used more commonly than in adult ICU, but as a specialty we are now using it less frequently (47), with recent reports estimating the use of long-term neuromuscular blockade in 14-16\% of ventilated days in PICU (48). Avoidance of prolonged use is preferable due to the risks of critical care polyneuropathy (49) and drug accumulation, which may result in delayed extubation.

Withdrawal phenomena remain a major concern in those patients who have received sedation over many days. Symptoms can include sweating, tachycardia, hypertension, agitation, posturing, withdrawal, vomiting and diarrhoea. Occasionally this prompts concerns of, and investigation for, cardiac, neurological or gastrointestinal disease. The alpha-2 agonist clonidine, chlorpromazine, and haloperidol can be used effectively to moderate these effects and the patients discharged to wards on a weaning oral regimen over a period of 7-14 days. Concerns remain about abrupt cessation of clonidine and the risk of rebound hypertension.

\section{Assessment of Pain and Sedation}

Sedation is administered to critically ill children according to predicted requirement. This may not, however, reflect actual requirements, with significant individual variation. 
Assessment of depth of sedation, with titration of analgesic and sedative drugs, is important to ensure comfort and avoid adverse outcomes, associated with under or over-sedation. Several scales, assessing behavioral and/ or physiological measures have been developed and validated for this purpose. These include 'The COMFORT Scale', an objective measure of distress in ventilated pediatric patients, validated in all age groups (50-51). It comprises 8 variables, each rated 1-5: alertness, calmness/agitation, respiratory response, physical movement, heart rate, blood pressure, muscle tone and facial tension, the scale ranging from $0-40$, with a target range of 17-26. As with other scoring systems it is limited by interobserver variability, provides only intermittent data and cannot be used in the context of neuromuscular (NMJ) blockade. Cardiovascular responses are also difficult to assess in patients who are paced.

Neurophysiological methods and auditory evoked potentials have been evaluated in the research domain. Bispectral Index (BIS) monitoring utilizes data from electroencephalogram (EEG) to measure depth of anesthesia. This technique assumes changes in frequency are related and looks for phase coupling among frequency bands (biocoherance) (52-53). In awake individuals, there is minimal synchronisation due to multiple signal generators within the brain, wheras during sleep, there is less activity and the EEG reflects coupling between signal generators (52-53). A dimensionless value, 'the BIS number', is calculated, which ranges from $0-100,0$ indicating an isoelectric state, with 100 correlating with a fully awake individual. Values of 40-60 are seen with general anesthesia (54). While it may provide an accurate assessment of depth of sedation for single agents such as midazolam, propofol and volatile agents, this is not the case for opiates or ketamine (55-56). Furthermore, Messner et $a l$., demonstrated BIS Index to decline, with NMJ blockade in awake volunteers, suggesting it may not identify those inadequately sedated under muscle relaxant (57). The BIS monitor is age-dependant (58) and currently there is insufficient evidence to support routine use of the BIS monitor, or any other neurophysiological sedation scoring technique, in PICU (59).

\section{Future prospects}

The concept of using the volatile agents for longer-term sedation on ICU's in not a new one. Barriers in the past have been ways to safely deliver the drug (vaporisers) as well as protecting the staff and environment (scavenging systems). A few ICU ventilators in the past such as the servo 900c were able to provide a plug on vaporiser to deliver isoflurane to the critically ill patient, but these are now generally obsolete. Adult data has shown that 
isoflurane can be an effective and practical sedative drug in the intensive care unit when combined with opioids with few side effects (60-61). More recently, Meiser and others have shown the rapidly eliminated inhalational agent desflurane to have characteristics that make it superior to other more conventional agents (62). The data in PICU is very limited. The early 10 patient study by Arnold et al. (63) used relatively high doses of isoflurane as a single agent in patients who had already become tolerant to opioids. Their results showed that while the drug was effective, there was a high incidence $(50 \%)$ of tolerance agitation and dystonia on withdrawal of the drug. More recent reports, particularly for treatment of status asthmaticus, as part of a more balanced sedative regimen, have been more encouraging (6465). However there is major lack of good prospective data to evaluate the potential of these drugs in PICU.

The renewed interest in gaseous sedative agents is likely to continue with developments of new delivery systems within ICU. Early studies with xenon show great potential in the clinical areas of the developing neonate and neurological injury (66-67). Unlike many PICU sedative agents, including midazolam, ketamine and other volatile anesthetic agents, xenon has been shown in animal models to provide anesthesia and sedation without producing apoptosis (68). Further studies have found that xenon can offer protection from hypoxic injury. Hobbs et al. demonstrated that rat pups exposed to hypoxic injury had a significantly better outcome with the combination of cooling to $32^{\circ} \mathrm{C}$ and xenon. The functional improvement with this regimen was almost complete, sustained long-term, and accompanied by greatly improved histopathology (69). Chakkrapani and colleagues demonstrated similar neuroprotective benefits of xenon, with synergistic effects seen with hypothermia in asphyxiated newborn piglets (70). Issues still remain if this drug is to become viable in PICU. It is rare, expensive and requires a closed system of delivery, which necessitates the developmet of new ventilatory systems. 


\section{References}

1. Tonner P, Weiler N. Sedation and anlagesia in the intensive care unit. Curr Opin Anaesthesiol 2003;16(2):113-21.

2. Kehlet H, Holte K. Effect of postoperative analgesia on surgical outcome. $\mathrm{Br} J$ Anaesth 2001;87(1):62-72.

3. Walker S, Franck LS, Fitzgerald M et al. Long-term impact of neonatal intensive care and surgery on somatosensory perception in children born extremely preterm. Pain 2009;141(1-2):78-87.

4. Tobias J. Tolerance, withdrawal, and physical dependency after long-term sedation and analgesia of children in the pediatric intensive care unit. Crit Care Med 2000;28(6):212232 .

5. Murray D, Thorne GC, Rigby-Jones AE et al. Electroencephalograph variables, drug concentrations and sedation scores in children emerging from propofol infusion anaesthesia. Pediatr Anaesth 2004;14(2):143-51.

6. Bonhomme V, Hans P. Muscle relaxation and depth of anaesthesia: where is the missing link? Br J Anaesth 2007;99(4):456-60.

7. Hiller A, Meretoja OA, Piiparinen S et al. The Analgesic Efficacy of Acetaminophen, Ketoprofen, or Their Combination for Pediatric Surgical Patients Having Soft Tissue or Orthopedic Procedures. Anesth Analg 2006;102(5):1365-71.

8. Anand K, Hickey PR. Halothane-morphine compared with high dose sufentanil for anaesthesia and postoperative analgesia in neonatal cardiac surgery. New Eng J Med 1992;326:1-9.

9. Gruber E, Laussen P, Casta A et al. Stress response in infants undergoing cardiac surgery: a randomised study of fentanyl bolus, fentanyl infusion and fentanyl-midazolam infusion. Anesth Analg 2001;92:882-90

10. Hickey P, Hansen D. High-dose fentanyl reduces intraoperative ventricular fibrillation in neonates with hypoplastic left heart syndrome. J Clin Anesth 1991;3:285-300.

11. Hickey PR, Hansen DD, Wessell DL et al. Blunting of stress responses in the pulmonary circulation of infants by fentanyl. Anesth Analg 1985;64:1137-42.

12. Duncan H, Clode A, Weir PM et al. Infant stress responses in the pre bypass phase of open heart surgery: a comparison of different fentanyl doses. Br J Anaesth 2000;84:556-65.

13. Anand K, Whit Hall R, Desai N et al. Effects of morphine analgesia in ventilated preterm neonates: primary outcomes from the NEOPAIN randomised trial. Lancet 2004;363(9422):1673-82. 
14. Lynn A, Nespeca NK, Bratton SL. Clearance of morphine in postoperative infants during intravenous infusion: the influence of age and surgery. Anesth Analg 1998;86(5):95863.

15. Rigby-Jones A, Priston MJ, Sneyd JR et al. Remifentanil-midazolam sedation for pediatric patients receiving mechanical ventilation after cardiac surgery. Br J Anaesth 2007;99(2):252-61.

16. Guignard B, Bossard AE, Coste $\mathrm{C}$ et al. Acute opioid tolerance: intraoperative remifentanil increases postoperative pain and morphine requirement. Anaesthesiology 2000;93(2):409-17.

17. Arnold J, Truog R, Scavone $\mathrm{J}$ et al. Changes in the pharmacodynamic response to fentanyl in neonates during continuous infusion. J Pediatr 1991;119(4):639-43.

18. Greeley W, Debruijn N. Changes in sufentanil pharmacokinetics within the neonatal period. Anesthesia and Analgesia 1998;67:86-90.

19. Bower S, Hull CJ. Comparative pharmacokinetics of fentanyl and alfentanil. $\mathrm{Br} J$ Anaesth 1982;54:871-7

20. Ross A, Davis P, Dear G et al. Pharmacokinetics of remifentanil in anesthetised pediatric patients undergoing elective surgery or diagnostic procedures. Anesth Analg 2001;93:1393-401.

21. Davis P, Wilson A, Siewers R et al. The effects of cardiopulmonary bypass on remifentanil kinetics in children undergoing atrial septal defect repair. Anesth Analg 1999;89:904-8.

22. Weale N, Rogers C, Cooper R et al. Effect of remifentanil infusion rate on stress response to the pre-bypass phase of pediatric cardiac surgery. Br J Anaesth 2004;92(3):1-8.

23. Vinik H, Kissin I. Rapid development of tolerance to analgesia during remifentanil infusion in humans. Anesthesia and Analgesia 1998;86:1307-11.

24. Friesen R, Veit A, Archibald D et al. A comparison of remifentanil and fentanyl for fast track paediatric cardiac surgery. Paediatric Anaesthesia 2003;13(2):122-5.

25. Verghese ST HR, Brennan M et al. The effect of intranasal administration of remifentanil on intubating conditions and airway responses after sevoflurane induction of anaesthesia in children. Anesth Analg 2008;107(4):1176-81.

26. Nestler E. Molecular basis of long-term plasticity underlying addiction. Nat Rev Neurosci 2001;2(2):119-28.

27. Eisch A, Barrott M, Schad CA. Opiates inhibit neurogenesis in the adult rodent dentate gyrus. Natl Acad Sci USA 2000;97(13):7579-84. 
28. $\mathrm{Pu} \mathrm{L}, \mathrm{Bao} \mathrm{G}-\mathrm{B}, \mathrm{Xu} \mathrm{N}-\mathrm{J}$ et al. Hippocampal long-term potentiation is reduced by chronic opiate treatment and can be restored by re-exposure to opiates. $J$ Neurosci 2002;22(5):1914-21.

29. Pronovost P ND, Berenholtz $\mathrm{S}$ et al. An intervention to decrease catheter-related bloodstream infections in the ICU. N Engl J Med 2006;355(26):2725-32.

30. Chipont Benabent E, Garcia-Hermosa P, Alio Y Sanz JL. [Suture of skin lacerations using LAT gel (lidocaine, adrenaline, tetracaine)]. Arch Soc Esp Oftalmol 2001;76(8):505-8.

31. Ernst A, Marvez-Valls E, Nick TG et al. Topical lidocaine adrenaline tetracaine (LAT gel) versus injectable buffered lidocaine for local anaesthesia in laceration repair. West J Med 1997;167(2):79-81.

32. Thammasitboon S, Lutfi R, Ely BA et al. Epidural analgesia promotes immediate tracheal extubation without complications in infants, children and young adults after cardiac surgery. Pediatr Anaesth ('in press').

33. Peterson K, DeCampli WM, Pike NA. A report of two hundred twenty cases of regional anesthesia in pediatric cardiac surgery. Anesthesia and Analgesia 2000;90:1014-9.

34. Hammer G, Ngos K, Macario A. A retrospective examination of regional plus general anesthesia in children undergoing open heart surgery. Anesthesia and Analgesia 2000;90:1020-4.

35. Humphreys N, Bays S, Parry AJ et al. Spinal anesthesia with an indwelling catheter reduces the stress response in pediatric open heart surgery. Anesthesiology 2005;103(6):111320.

36. Sanders R, Hussell T, Maze M. Sedation and immunomodulation. Crit Care Clin 2009;25(3):551-70.

37. Galley H, DiMatteo MA, Webster NR. Immunomodulation by anaesthetic, sedative and analgesic agents: does it matter? Intensive Care Med 2000;26(3):267-74.

38. Fraser R, Watt I, Gray CE et al. The effect of etomidate on adrenocortical function in dogs before and during hemorrhagic shock. Endocrinology 1984;115(6):2266-70.

39. Vasile B, Rasulo F, Candiani A et al. The pathophysiology of propofol infusion syndrome: a simple name for a complex syndrome. Intensive Care Med 2003;29(9):1417-25.

40. Scott N, Terfrey DJ, Ray DA et al. A prospective randomised study of the potential benefits of thoracic epidural anesthesia and analgesia in patients undergoing coronary artery bypass grafting. Anesth Analg 2001;93:523-35.

41. Vricella L, Dearani JA, Gundry SR et al. Ultra fast track in elective congenital cardiac surgery. Ann Thorac Surg 2000;69:865-71.

42. Heinle J, Diaz LK, Fox LS et al. Early extubation after cardiac operations in neonates and young infants. Journal of Thoracic and Cardiovascular Surgery 1998;114:413-8. 
43. Shekerdemian L, Bush A, Shore DF et al. Cardiopulmonary interactions after Fontan operations. Circulation 1997;96:3934-42.

44. Wolf A, Potter F. Propofol infusions in children: when does an anaesthetic tool become an intensive care liability. Pediatr Anaesth 2004;17:675-83.

45. Jenkins I, Playfor S, Bevan C et al for the Sedation Working Party, Pediatric Intensive Care Society Study Group, UK. Current United Kingdom sedation practice in pediatric intensive care. Pediatric Anaesthesia 2007;17:675-83.

46. Playfor S, Jenkins I, Boyles $\mathrm{C}$ et al. Consensus guidelines for sustained neuromuscular blockade in critically ill children. Paediatr Anaesth 2007;17(9):881-7.

47. Merriman HM. The techniques used to sedate ventilated patients. A survey of methods used in 34 ICUs in Great Britain. Intensive Care Med 1981;7(5):217-24.

48. Martin LD, Bratton SL, Quint P et al. Prospective documentation of sedative, analgesic, and neurouscular blocking agent use in infants and children in the intensive care unit: A multicenter perspective. Pediatr Crit Care Med 2001;2(3):205-10.

49. Tabarki B, Coffinieres A, van den Bergh P et al. Critical illness neuromuscular disease: Clinical, electrophsiological, and prognostic aspects. Arch Dis Child 2002;86:103-7.

50. Ambuel B, Hamlett KW, Marx CM et al. Assessing distress in pediatric intensive care enviroments: the COMFORT scale. J Pediatr Psychol 1992;17(1):95-109.

51. Van Dijk M, de Boer JB, Koot HM et al. The reliability and validity of the COMFORT scale as a postoperative pain instrument in 0 to 3 -year-old infants. Pain 2000;84:367-77.

52. Raimer PL, Shanley, TP. Bispectral Index Monitoring in the PICU. In: Shanley TP, Zimmerman JJ, eds. Current Concepts in Pediatric Critical Care. Illinois, IL: SCCM; 2008:89-93.

53. Bispectral electroencephalographic monitoring. In: Steotling RK, Miller RD eds. Anesthesia. 5th edn. New York, NY: Churchill Livingstone. 2006.

54. Rampril I. A primer for EEG signal processing in anesthesia. Anesthesiology 1998;89:980-1002.

55. Shields CH, Stayadi-Park G, McGown MY et al. Clinical Utility of the Bispectral Index score when compared to the University of Michigan Sedaton Scale in assessing the depth of outpatient pediatric sedation. Clin Pediatr 2005;44(3):229-36.

56. Aneja R, Heard A, Fletcher J et al. Sedation monitoring of children by the Bispectral Index in the paediatric intensive care unit. Pediatr Crit Care Med 2003;4(1):60-4.

57. Messner M, Besse U, Romstock J et al. The Bispectral index declines during neuromuscular block in fully awake persons. Anesth Analg 2003;97:488-91. 
58. Davidson A, McCann ME, Devavaram P et al. The differences in the bispectral index between infants and children during emergence from anesthesia after circumcision surgery. Anesth Analg 2001;93:326-30.

59. Playfor S. The use of bispectral index monitors in paediatric intensive care. Critical Care 2005;9:25-6.

60. Millane T, Bennett ED, Grounds RM. Isoflurane and propofol for long-term sedation in the intensive care unit. A crossover study. Anaesthesia 1992;47(9):768-74.

61. Spencer E, Willatts SM. Isoflurane for prolonged sedation in the intensive care unit; efficacy and safety. Intensive Care Med 1992;18(7):415-21.

62. Meiser A, Sirtl C, Bellgardt M et al. Desflurane compared with propofol for postoperative sedation in the intensive care unit. Br J Anaesth 2003;90(3):273-80.

63. Arnold J, Truog RD, Rice SA. Prolonged administration of isoflurane in pediatric patients during mechanical ventilation. Br J Anaesth 1993;90(3):273-80.

64. Wheeler D, Clap CR, Ponaman ML. Isoflurane therapy for status asthmaticus in children: A case series and protocol. Paediatr Crit Care Med 2000;1(1):5-59.

65. Shanker V, Churchwell KB, Deshpande JK. Isoflurane therepy for severe refractory status asthmaticus in children. Intensive Care Med 2004;32(6):927-33.

66. Bedi A, Murray JM, Dingley $\mathrm{J}$ et al. Use of xenon as a sedative for patients receiving critical care. Crit Care Med 2003;31(10):2470-7.

67. Sanders R, Ma D, Maze M. Xenon: elemental anaesthesia in clinical practice. $\mathrm{Br}$ Med Bull 2004;71:115-35.

68. Ma D, Williamson P, Januszewski A et al. Xenon mitigates isoflurane-induced neuronal apoptosis in the developing rodent brain. Anesthesiology 2007;106(4):746-53.

69. Hobbs C, Thoreson M, Tucker A et al. Xenon and hypothermia combine additively, offering long-term functional and histopathologic neuroprotection after neonatal hypoxia/ischaemia. Stroke 2008;39(4):1307-13.

70. Chakkarapani E, Dingley J, Hoque N et al. Xenon enhances hypothermic neuroprotection in asphyxiated newborn pigs. Annals of Neurology 2010;doi.10.1002/ana.22016. 


\section{Table 1: Opioid Analgesia}

\begin{tabular}{|c|c|c|c|c|}
\hline Drug & Indications & Dose & Elimination & Comments \\
\hline $\begin{array}{l}\text { Fentanyl } \\
\text { Infusion }\end{array}$ & $\begin{array}{l}\text { Analgesia } \\
\text { Intense } \\
\text { analgesia/anesthesia } \\
\text { in ventilated patients }\end{array}$ & $\begin{array}{l}1-5 \mu \mathrm{g} \mathrm{kg}^{\mathrm{h}} \mathrm{hr}^{-1} \\
1-15 \mu \mathrm{g} \cdot \mathrm{kg} \cdot \mathrm{hr}^{-1}\end{array}$ & Hepatic metabolism & $\begin{array}{l}\text { Large bolus doses can cause } \\
\text { hypotension } \\
\text { Ventilatory depression }\end{array}$ \\
\hline Bolus Fentanyl & $\begin{array}{l}\text { Pulmonary } \\
\text { hypertension }\end{array}$ & $10-50 \mu \mathrm{g} \mathrm{kg}^{-1}$ & & $\begin{array}{l}\text { Neonates may have long } \\
\text { elimination half-lives, with } \\
\text { delayed recovery }\end{array}$ \\
\hline Oral morphine & $\begin{array}{l}\text { Analgesia with } \\
\text { sedation } \\
\text { Controlled analgesia } \\
\text { in the extubated } \\
\text { patient } \\
\text { Longer-term } \\
\text { analgesia once } \\
\text { absorption has } \\
\text { recovered }\end{array}$ & 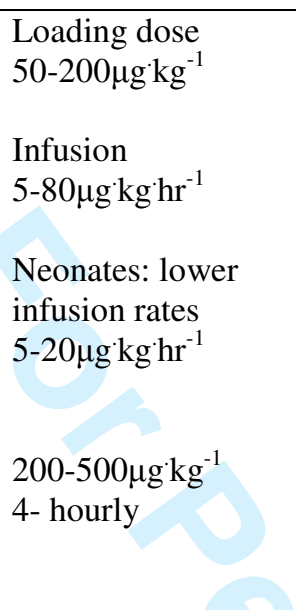 & $\begin{array}{l}\text { Hepatic followed by } \\
\text { renal excretion of } \\
\text { active metabolite } \\
\text { (morphine-6- } \\
\text { glucuronide) }\end{array}$ & $\begin{array}{l}\text { Delayed recovery in neonates } \\
\text { Nausea and vomiting can be } \\
\text { problematic in older children } \\
\text { Reduced doses may be needed } \\
\text { with renal impairment due to } \\
\text { accumulation of morphine-6- } \\
\text { glucuronide } \\
\text { Oral doses need to be larger } \\
\text { than IV doses due to reduced } \\
\text { bioavailability and first pass } \\
\text { metabolism }\end{array}$ \\
\hline $\begin{array}{l}\text { Alfentanil } \\
\text { Infusion }\end{array}$ & $\begin{array}{l}\text { Rapid offset, useful } \\
\text { for fast track surgery }\end{array}$ & $\begin{array}{l}\text { Loading dose: } \\
50-100 \mu \mathrm{g} \cdot \mathrm{kg}^{-1} \\
\text { Infusion: } \\
0.5-2 \mu \mathrm{g} \cdot \mathrm{kg} \cdot \mathrm{min}^{-1}\end{array}$ & $\begin{array}{l}\text { Hepatic metabolism } \\
\text { Highly protein bound } \\
\text { with a small volume } \\
\text { of distribution. }\end{array}$ & $\begin{array}{l}\text { Small volume of distribution } \\
\text { and short elimination half-life } \\
\text { make its offset very rapid }\end{array}$ \\
\hline Remifentanil & $\begin{array}{l}\text { Infusion in ventilated } \\
\text { patients } \\
\text { Intense, rapid } \\
\text { onset/offset (largely } \\
\text { independent of age } \\
\text { or infusion duration) }\end{array}$ & $\begin{array}{l}\text { Analgesia: } \\
0.1-0.3 \mu \mathrm{g} \cdot \mathrm{kg} \cdot \mathrm{min}^{-1} \\
\text { Anaesthesia: } \\
0.5-1.5 \mu \mathrm{g} \cdot \mathrm{kg} \cdot \mathrm{min}^{-1}\end{array}$ & $\begin{array}{l}\text { Metabolised rapidly } \\
\text { by plasma and tissue } \\
\text { cholinesterases. }\end{array}$ & $\begin{array}{l}\text { Alternative analgesia is required } \\
\text { before the infusion is stopped } \\
\text { Unsuitable for the extubated, } \\
\text { spontaneously breathing patient }\end{array}$ \\
\hline $\begin{array}{l}\text { Codeine } \\
\text { Phosphate }\end{array}$ & Oral medication & $\begin{array}{l}\text { Neonate: } \\
0.5-1 \mu \mathrm{kg}^{-1} \\
\text { Child up to } 12 \mathrm{yrs} \text { : } \\
0.5-1 \mathrm{mg}^{-1} \mathrm{~kg}^{-1} \\
\text { Max daily: } 240 \mathrm{mg} \\
>12 \text { years:30-60mg }\end{array}$ & $\begin{array}{l}\text { Hepatic and renal } \\
\text { clearance }\end{array}$ & $\begin{array}{l}\text { Also used for treatment of } \\
\text { diarrhoea due to constipating } \\
\text { effects }\end{array}$ \\
\hline Tramadol & Oral medication & $\begin{array}{l}\text { >12 years: } \\
50-100 \mathrm{mg} 4-6 \\
\text { hourly } \\
\text { Max daily: } 400 \mathrm{mg}\end{array}$ & $\begin{array}{l}\text { Hepatic and renal } \\
\text { clearance }\end{array}$ & $\begin{array}{l}\text { Only patients }>12 \text { years } \\
\text { Nausea, vomiting, constipation } \\
\text { Respiratory depression in } \\
\text { large doses }\end{array}$ \\
\hline
\end{tabular}




\begin{tabular}{|c|c|c|c|}
\hline Drug & Indications & Dose & Comments \\
\hline Paracetamol & $\begin{array}{l}\text { Hyperthermia } \\
\text { Co-analgesia with } \\
\text { opioids }\end{array}$ & $\begin{array}{l}0-3 \text { months loading dose: oral } \\
20 \mathrm{mg} \mathrm{kg}^{-1} \text {, rectal } 30 \mathrm{mg} \mathrm{kg}^{-1} \\
\text { Max daily } 90 \mathrm{mg} \mathrm{kg}^{-1} \text { (max } \\
\text { adult } 4 \mathrm{~g} \text { daily) for } 48 \mathrm{hrs} \\
\text { reduce thereafter to } 60 \mathrm{mg} \mathrm{kg}^{-1}\end{array}$ & $\begin{array}{l}\text { Significant but low analgesic } \\
\text { potency } \\
\text { Reduced doses may be needed } \\
\text { in the critically ill fluid } \\
\text { restricted child to avoid hepatic } \\
\text { dysfunction and toxicity }\end{array}$ \\
\hline Diclofenac $*$ & $\begin{array}{l}\text { Opioid sparing } \\
\text { analgesia } \\
\text { Not used under } 1 \text { year } \\
\text { or with significant } \\
\text { asthma } \\
\text { As above }\end{array}$ & $\begin{array}{l}\text { Oral or rectal: } 1 \mathrm{mgkg}^{-1} \\
\text { Max daily: } 3 \mathrm{mg} \mathrm{kg}^{-1} \\
\text { Oral or rectal: } 10 \mathrm{mgkg}^{-1} \\
\text { Max daily: } 40 \mathrm{mg} \mathrm{kg}^{-1}\end{array}$ & $\begin{array}{l}\text { Has effects on gastric mucosa } \\
\text { and platelet function } \\
\text { Can be nephrotoxic } \\
\text { As above }\end{array}$ \\
\hline Ketamine & $\begin{array}{l}\text { Alternative intravenous } \\
\text { analgesia to opioids } \\
\text { (NMDA receptor } \\
\text { antagonist) }\end{array}$ & $\begin{array}{l}\text { IV infusion: } \\
\text { 10-45 } \mu \mathrm{g} \cdot \mathrm{kg} \cdot \mathrm{min}^{-1}\end{array}$ & $\begin{array}{l}\text { Can be used in spontaneously } \\
\text { breathing children } \\
\text { Associated with dysphoria when } \\
\text { used as a sole agent } \\
\text { May provide useful } \\
\text { bronchodilation }\end{array}$ \\
\hline Clonidine & $\begin{array}{l}\text { Less analgesic potency } \\
\text { than morphine but can } \\
\text { be used as co-analgesia } \\
\text { (orally), for longer-term } \\
\text { sedation, or for } \\
\text { withdrawal from } \\
\text { opioids ( } \alpha \text {-2-agonist) }\end{array}$ & $\begin{array}{l}\text { Intravenous infusion: } \\
0.5-3.0 \mu \mathrm{g} \cdot \mathrm{kg} \cdot \mathrm{min}^{-1} \\
\text { Oral: } \\
2-5 \mu \mathrm{g} \mathrm{kg}^{-1} \text { 4-hourly }\end{array}$ & $\begin{array}{l}\text { Can cause hypotension and } \\
\text { bradycardia } \\
\text { Rebound hypertension has been } \\
\text { described in adults }\end{array}$ \\
\hline
\end{tabular}

\section{Table 2: Non-Opioid Analgesia}

*These drugs are used extensively outside their product licence but within recommended guidelines from the Royal College of Paediatrics and Child Health. Prevention and Control of Pain in Children 1997: BMJ Publishing Group, London 


\begin{tabular}{|c|c|c|c|}
\hline Drug & Benefits & Dose & Comments \\
\hline $\begin{array}{l}\text { Benzodiazepines } \\
\text { Midazolam }\end{array}$ & $\begin{array}{l}\text { Amnesic benefit in } \\
\text { addition to sedation }\end{array}$ & $\begin{array}{l}\text { Intravenous infusion: } \\
\text { max } 200 \mu \mathrm{g} \mathrm{kg}^{-1} \\
\text { Intranasal: } \\
0.1 \mathrm{mg} \mathrm{kg}^{-1} \text { each nostril }\end{array}$ & $\begin{array}{l}\text { High risk of withdrawal } \\
\text { with prolonged use or high } \\
\text { doses }\left(>100 \mu \mathrm{g} \mathrm{kghr}^{-1}\right) \text {. } \\
\text { Helps control seizures }\end{array}$ \\
\hline Lorazepam & $\begin{array}{l}\text { Oral drug useful in } \\
\text { midazolam withdrawal }\end{array}$ & & $\begin{array}{l}\text { Risk of respiratory } \\
\text { depression - particularly } \\
\text { with repeated doses }\end{array}$ \\
\hline Diazepam & $\begin{array}{l}\text { Status epilepticus } \\
\text { (rectal) }\end{array}$ & $\begin{array}{l}\text { Rectal: } \\
\text { Neonate: } \max 2.5 \mathrm{mg} \\
1 \text { month-2years: } 5 \mathrm{mg} \\
2-12 \text { years: } 5-10 \mathrm{mg} \\
12-18 \text { years: } 10 \mathrm{mg}\end{array}$ & \\
\hline Propofol & $\begin{array}{l}\text { Short term action - } \\
\text { rapid wake up }\end{array}$ & $\begin{array}{l}\text { Intravenous infusion: } \\
\text { max } 4 \mathrm{mg} \mathrm{kg}^{-1} \mathrm{hr}^{-1} \\
\text { Titrate to effect } \\
\\
\text { Check for rising lactate } \\
\text { or acidosis, limit } \\
\text { infusion duration }\end{array}$ & $\begin{array}{l}\text { Hypotension } \\
\text { Risk of propofol infusion } \\
\text { syndrome. Lipid load with } \\
\text { infusion. Contraindicated } \\
\text { by FDA }\end{array}$ \\
\hline $\begin{array}{l}\text { Phenothiazines } \\
\text { (Chlorpromazine } \\
\text { hydrochloride) }\end{array}$ & Dissociated sedation & $\begin{array}{l}\text { Oral or IV: } \\
500 \mu \mathrm{g} \mathrm{kg}^{-1}\end{array}$ & $\begin{array}{l}\text { Risk of extrapyramidal } \\
\text { side effects }\end{array}$ \\
\hline $\begin{array}{l}\text { Butyrophenones } \\
\text { (Haloperidol) }\end{array}$ & Dissociated sedation & $\begin{array}{l}\text { Intravenous infusion: } \\
\text { 1month-12 years: } \\
25-85 \mu \mathrm{g} \mathrm{kg}{ }^{-1} \text { over } 24 \\
\text { hours } \\
12-18 \text { years: } \\
1.5-5 \mathrm{mg} \text { over } 24 \text { hours }\end{array}$ & $\begin{array}{l}\text { Risk of extrapyramidal } \\
\text { side effects }\end{array}$ \\
\hline Clonidine & $\begin{array}{l}\text { Withdrawal } \\
\text { Analgesic properties } \\
\text { with opiate-sparing } \\
\text { effect }\end{array}$ & $\begin{array}{l}\text { Intravenous infusion: } \\
0.5-3.0 \mu \mathrm{g} / \mathrm{kg} / \mathrm{min} \\
\text { Oral: } \\
2-5 \mu \mathrm{g} \mathrm{kg}^{-1} \text { 4-hourly }\end{array}$ & $\begin{array}{l}\text { Can cause hypotension and } \\
\text { bradycardia } \\
\text { Rebound hypertension } \\
\text { described in adults }\end{array}$ \\
\hline Volatile agents & $\begin{array}{l}\text { Rapid clearance for } \\
\text { quick wake up }\end{array}$ & $\begin{array}{l}\text { Dose titrated to effect } \\
\text { Depends on delivery } \\
\text { system and gas flows }\end{array}$ & $\begin{array}{l}\text { Can be useful for } \\
\text { bronchospasm and seizures } \\
\text { Requires vapouriser and } \\
\text { scavenger systems }\end{array}$ \\
\hline Chloral hydrate & Well tolerated & $\begin{array}{l}\text { Oral or rectal: } \\
25-50 \mathrm{mg} \mathrm{kg}^{-1}\end{array}$ & $\begin{array}{l}\text { Delayed clearance in } \\
\text { neonates - be wary with } \\
\text { regular dosing }\end{array}$ \\
\hline
\end{tabular}

Table 3: Sedative Drugs 